\title{
Evaluation of herbaceous crops irrigated with treated wastewater for ethanol production
}

\author{
Salvatore Barbagallo, 1,4 Antonio Barbera, 2,3 Giuseppe L. Cirelli Giuseppe, ${ }^{1,4}$ Mirco Milani, 1,4 \\ Attilio Toscano, ${ }^{1,4}$ Roberto Albergo Roberto ${ }^{3}$ \\ ${ }^{1}$ Department of Agri-food and Environmental Systems Management, University of Catania, \\ Catania, Italy; ${ }^{2}$ Department of Food and Agricultural Production Sciences, University of Catania, \\ Catania, Italy, ${ }^{3}$ ENEA, Trisaia Research Centre, Rotondella (MT), Italy; ${ }^{4}$ CSEI Catania, Italy
}

\begin{abstract}
The competition for freshwater between agricultural, industrial, and civil uses has greatly increased in Mediterranean basin characterized by prolonged dry seasons. The aim of this study was to evaluate biomass production and the potential ethanol production of promising "no-food" herbaceous crops irrigated with low quality water at different ETc restitutions (0\%, 50 and 100\%). The research was carried out, in 2011 and 2012, in an open field near the full-scale constructed wetland (CW) municipal treatment plant located in the Eastern Sicily (Italy). The CW effluent has been applied in a experimental irrigation field of Vetiveria zizanoides (L.) Nash, Miscanthus $x$ giganteus Greef et Deu. and Arundo donax (L.). Physical, chemical and microbiological analyses were carried out on wastewater samples collected at inlet and outlet of CW and pollutant removal efficiencies were calculated for each parameter. Bio-agronomical analysis on herbaceous species were made with the goal to evaluate the main parameters such as the plant dimension, the growth response and the biomass production. Biomass dry samples were processed with a three-step chemical pretreatment, hydrolysed with a mix of commercial enzymes and next fermented to obtain the yield of ethanol production. Average TSS, COD and TN removal for CW were about $74 \%$, $67 \%$ and $68 \%$, respectively. Although the satisfactory Escherichia coli removal, about $3.5 \log$ unit for both beds on average, CW didn't
\end{abstract}

Correspondence: Mirco Milani.

Tel. +39.095 .7147543 - Fax: +39.095 .7147 .600 .

E-mail: mirco.milani@unict.it

Key words: constructed wetland, wastewater reuse, herbaceous crops, evapotranspiration replenishment, ethanol.

Acknowledgements: the research activity was supported by the MIUR (Italian Ministry of Education, University and Research) through the project FITOPROBIO "Production of macrophyte wetland biomasses irrigated with wastewater to obtain second-generation ethanol".

(C) Copyright S. Barbagallo et al., 2013

Licensee PAGEPress, Italy

Journal of Agricultural Engineering 2013; XLIV(s2):e110

doi:10.4081/jae.2013.s2.e110

This article is distributed under the terms of the Creative Commons Attribution Noncommercial License (by-nc 3.0) which permits any noncommercial use, distribution, and reproduction in any medium, provided the original author(s) and source are credited. achieve the restrictive Italian law limits for wastewater reuse. As expected, irrigation was beneficial and the full ET replenishment increase the biomass productivity as compared to the other two treatment. The mean productivity of Vetiveria zizanoides and Myscanthus $x$ giganteus were about 9,26 and $38 \mathrm{t} \mathrm{ha}^{-1}$ and 3,7 and $12 \mathrm{t} \mathrm{ha}^{-1}$ respectively in $0 \%, 50 \%$ and $100 \%$ ETc restitutions. Arundo donax gave higher values of dry biomass $\left(78 \mathrm{t} \mathrm{ha}^{-1}\right.$ in $100 \%$ ETc restitution in 2011 season), and potential ethanol production (about $3,744 \mathrm{~kg}$ $\mathrm{ha}^{-1}$ ). These results suggest the interest in the use of constructed wetland effluents for the irrigation of energy crops to obtain second generation ethanol, particularly in semiarid regions such as the Mediterranean area.

\section{Introduction}

The gradual depletion of petroleum-derived transportation fuels has focused attention on both renewable and environmentally friendly resources (Ge et al., 2011), with ethanol from plants being a possible alternative (Sivakumar et al., 2010). Ethanol produced from lignocellulosic biomass is one of the most suitable alternatives for partial replacements of fossil fuels because it provides energy that is renewable and less carbon intensive than gasoline. Bioethanol reduces air pollution and also contributes to mitigate climate change by reducing greenhouse gas emissions (Gnansounou, 2010).

The success of energy crops is closely linked to the production costs. For this reason it is preferable to grow perennial plants, because they need a limited soil management, and to adopt extensive cultivation systems. However, application of fertiliser and irrigation is generally necessary to achieve high crop productivity, especially in the Mediterranean zones, characterized by a chronic water shortage (Barbera et al., 2009). In this context, the irrigation wastewater reuse is desirable because conserve water resources, reduce disposal of polluted effluents into surface water bodies enhances the economic benefits for farmers due to reduced need for fertilizer (Paranychianakis et al., 2006) improve productivity of crops (Bedbabis et al., 2010).

A viable solution for wastewater treatment could be represented by constructed wetland (CW) which are characterised by low $0 \& M$ costs and by unskilled manpower requirements and represent environmentally sound alternatives to conventional wastewater treatment plants (Cirelli et al., 2007)

This research activity evaluated: 1) the performances of a constructed wetland (CW) system located in Southern Italy, and its suitability for reusing the effluent; 2) the biomass production of herbaceous species when irrigated with CW effluent; 3 ) the ethanol yield of three herbaceous species. 


\section{Materials and methods}

\section{Experimental plans}

The study was carried out in a full-scale constructed wetland treatment plant and in an open field of herbaceous species located in San Michele di Ganzaria (Eastern Sicily - Latitude $37^{\circ} 16^{\prime}$ North, Longitude $14^{\circ} 25^{\prime}$ East, altitude $350 \mathrm{~m}$ ), a rural community of about 5,000 inhabitants. Constructed wetland consists of two Horizontal SubSurface Flow beds (H-SSF1 and H-SSF2) that receive part of secondary effluent (4 $\mathrm{L} / \mathrm{s}$ ) of the conventional wastewater treatment plant of village (Barbagallo et al., 2011). H-SSF1 and H-SSF2 working in parallel and have an almost equal surface area (about 2,000 $\mathrm{m}^{2}$ ) but with different operation life: 12 and 6 years of functioning. The terminal section (190 $\mathrm{m}^{2}$ ) of H-SSF2 reed bed functions as a free water surface. Both reed beds was vegetated with Phragmites australis.

Wastewater treated by constructed wetlands has been used for irrigation of herbaceous crops. To this purpose, an experimental irrigation field of Vetiveria zizanoides (L.) Nash, Miscanthus $x$ giganteus Greef et Deu. and Arundo donax (L.) was established. V.zizanoides and M.giganteus were transplanted in six plot of $9 \mathrm{~m}^{2}$ (three repetitions for each species), in July 2008 and May 2009, respectively. A.donax was planted, in July 2008, on an area of about $1,000 \mathrm{~m}^{2}$ divided in three blocks of about $330 \mathrm{~m}^{2}$. All species were transplanted with a density of about 4 plants $/ \mathrm{m}^{2}$. The wastewaters were supplied by in-line labyrinth drippers system. A meteorological station was installed close to experimental plants, measuring rainfall, temperature, air moisture content, wind velocity, solar radiation and the evaporation. A CR510 automatic weather station (Campbell Scientific, Logan, UT) was installed close to the experimental site for the continuative measure of: rainfall, temperature, air moisture content, wind velocity, solar radiation and the evaporation.

\section{Wastewater irrigation}

The water volumes distributed were equal to $0 \%$ (S1 and S4), $50 \%$ (S2 and S5) and 100\% (S3 and S6) of evapotranspiration losses (ETc) (Figure 1).

Wastewater irrigation scheduling was based on water balance equation (Eq. (1)):

$\mathrm{I}=\mathrm{ETc}-\mathrm{P}+\mathrm{Dp}+\mathrm{Rf}$

Where I is irrigation water applied (mm), ETc, crop evapotranspira- tion (mm) rate calculated as product of Penman-Monteith based reference evapotranspiration (ET0) (ASCE-EWRI, 2004) and the FA0-56 crop coefficient (Kc). ET0 reference data were determined by daily climatic factors using an on-site weather station. Kc ranging from 0.75 to 1.10 for V.zizanoides and M.giganteus while for A.donax varied from 1.00 to 1.30. The terms Dp and Rf represent deep percolation ( $\mathrm{mm}$ ) and runoff $(\mathrm{mm})$, respectively. Since irrigation water was controlled, deep percolation and runoff were assumed negligible. The irrigations were realized from June to October 2011 and 2012.

\section{Analysis}

\section{Wastewater analysis}

Wastewater quality samples were collected at the inlet and outlet of H-SSF1 and H-SSF2. The following physicochemical parameters were evaluated according to APHA (1998) methods: electrical conductivity (EC), $\mathrm{pH}$, total suspended solids (TSS) at $105^{\circ} \mathrm{C}, \mathrm{COD}$, total nitrogen (TN) $\mathrm{NH}_{4}-\mathrm{N}$, Total Nitrogen (TN) and $\mathrm{PO}_{4}$-P. In order to evaluate the microbiological pollution Escherichia coli and Salmonella were also analyzed. $E$. coli was evaluated according to the standard methods (APHA, 1998) and Salmonella was examined according to the methodology reported in Barbagallo et al. (2003). For each CW were computed the percentage removal efficiencies, for physicochemical parameters, and the log reduction for microbiological parameters.

\section{Bio-agronomical analysis}

In the giant reed parcel were identified nine square sampling areas, of one meter side each, where the bio-agronomical survey and sampling activity were carried out during the experimental period. While in the V.zizanoides and M.giganteus were defined sampling areas of about $4 \mathrm{~m}^{2}$ in the centre of each plot. In the sampling area, bio-agronomical analysis on tested species were made with the goal to evaluate the main parameters such as the plant dimension, the growth response and the biomass production. Plant samples for the evaluation of productivity were taken in December 2011 and 2012. Biomass dry weight was determined by drying plant tissue samples in a thermo-ventilated oven at $65{ }^{\circ} \mathrm{C}$ until constant weight was reached.

At time of harvest, dry biomass samples of each species have been sent to the Biotechnical Laboratory ENEA in Trisaia in order to characterize each species in terms of fiber (hemicellulose, cellulose and lignin). Afterwards all of them were processed with a three-step chem-
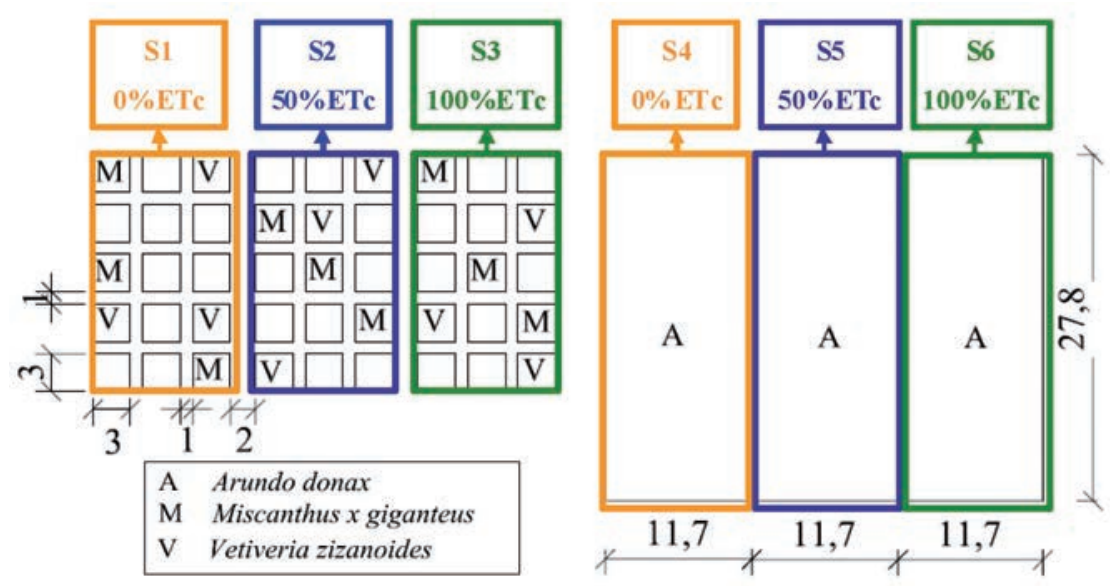

Figure 1. Layout of experimental plant for herbaceous crops. 
ical pretreatment to recover most of cellulose and make the biomass more accessible (Borin et al., 2011). This pretreated material was then hydrolysed with a mix of commercial enzymes and next fermented to obtain for each studied plant the yield of ethanol production.

\section{Results and discussion}

\section{Constructed wetland performance}

During the whole observation period the values of $\mathrm{pH}$ and $\mathrm{EC}$ of $\mathrm{CWs}$ influent and effluent were similar and varied in the range 6.9-7.8 and $1.1-1.7 \mathrm{mS} / \mathrm{cm}$, respectively.

Table 1 shows the average concentrations of the chemico-physical and microbiological parameters in and out of the CWs during the investigation period. The respective mean removal efficiencies are shown in Figure 2.

About $100 \%$ and $47 \%$ of TSS analysed samples in CWs influent resulted out, respectively, of legislation limits for wastewater reuse (D.M. 185/2003) and for wastewater discharge in water bodies (D.lgs. 152/2006). In the H-SSF1 and H-SSF2 effluent, average TSS concentrations ranged from 6 to $9 \mathrm{mg} / \mathrm{L}$ and from 8 to $12 \mathrm{mg} / \mathrm{L}$, respectively. The TSS Italian limit for wastewater irrigation reuse was only exceeded by $17 \%$ (H-SSF1) and 18\% (H-SSF2) of the samples.

In both effluents, COD and TN concentrations were always below the limits imposed by the D.lgs. 152/2006 and D.M. 185/2003, highlighting average removal efficiencies, respectively, of about 55 and $67 \%$ in $\mathrm{H}-$ SSF1 and 61 and 74\% in H-SSF2. Also the average $\mathrm{NH}_{4}-\mathrm{N}$ and $\mathrm{PO}_{4}-\mathrm{P}$ removal in H-SSF1 (63\% and 26\%) was lower than in H-SSF2 (71\% and $48 \%$ ). This results could by explained by ability of algae and microphytes to remove the nutrient elements directly on the open water surface at the end of H-SSF2.

The performance was good for Salmonella removal, which was never detected in the effluent of CWs. During the 2012 observation period the E.coli concentration in the HSSF2 effluent showed an average decrease of $3.5 \log$ units and $3.0 \log$ units in the H-SSF1 effluent. Only $40 \%$ of total samples matched the limit of E.coli fixed by D.M. 185/2003. However, the E.coli concentration in the H-SSF1 and H-SSF2 effluent (always equal or less $10^{3} \mathrm{UFC} / 100 \mathrm{~mL}$ ) ensure that health-based targets proposed by the WHO (2006) are matched particularly if drip irrigation is used.

\section{Herbaceous crops: biomass and ethanol productivity}

\section{Environmental conditions and irrigation volumes}

During the two growing seasons, the daily minimum air temperatures ranged from -4.3 to $22.2^{\circ} \mathrm{C}$ and the maximum from 7.1 to $43.3^{\circ} \mathrm{C}$ with average seasonal values of $18.8{ }^{\circ} \mathrm{C}(2011)$ and $19.9^{\circ} \mathrm{C}(2012)$. Total rainfall from March to October was $406 \mathrm{~mm}$ in 2011 while in 2012 it was only $163 \mathrm{~mm}$ (Figure 3), with 179 and 197 days without rain, respectively.

The higher temperature associated with lower precipitation in 2012 irrigation period compared to the same period in 2011 generated the significantly different ETc values. In particular, irrigation water volumes applied in V.zizanoides and M.giganteus crops were $250 \mathrm{~mm}$ and $480 \mathrm{~mm}$ (2011 season) and $380 \mathrm{~mm}$ and $780 \mathrm{~mm}$ (2012 season) at plots

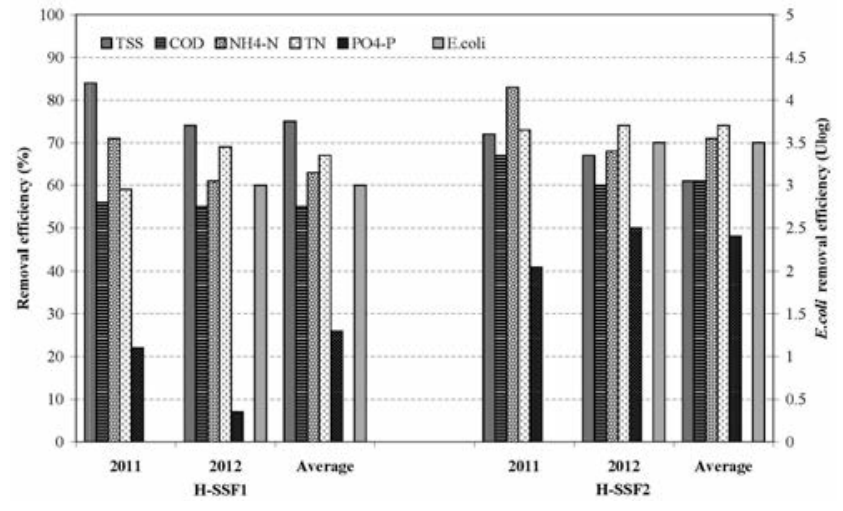

Figure 2. CWs removal efficiency of TSS, COD, $\mathrm{NH}_{4}-\mathrm{N}, \mathrm{TN}, \mathrm{PO} 4-\mathrm{P}$ and E. coli during the observation period

Table 1. Comparison between average pollutant wastewater concentration in the influent (In) and effluent (Out) of H-SSF1 and H-SSF2 with the Italian wastewater discharge limits into surface waters (D.Lgs. 152/2006) and for agriculture reuse (D.M. 185/2003).

\begin{tabular}{|c|c|c|c|c|c|c|c|c|c|c|c|c|c|c|}
\hline \multirow[t]{3}{*}{ Parameters } & \multicolumn{4}{|c|}{2011} & \multicolumn{4}{|c|}{2012} & \multicolumn{4}{|c|}{ Average } & \multicolumn{2}{|c|}{ Law Limits } \\
\hline & \multicolumn{2}{|c|}{ H-SSF1 } & \multicolumn{2}{|c|}{ H-SSF2 } & \multicolumn{2}{|c|}{ H-SSF1 } & \multicolumn{2}{|c|}{ H-SSF2 } & \multicolumn{2}{|c|}{ H-SSF1 } & \multicolumn{2}{|c|}{ H-SSF2 } & \multirow{2}{*}{$\begin{array}{l}\text { D.Lgs. } \\
152 / 06\end{array}$} & \multirow{2}{*}{$\begin{array}{l}\text { D.M. } \\
\text { 185/03 }\end{array}$} \\
\hline & In & Out & In & Out & In & Out & In & Out & In & Out & In & Out & & \\
\hline $\begin{array}{l}\text { TSS } \\
(\mathrm{mg} / \mathrm{L})\end{array}$ & 63 & 9 & 63 & 12 & 42 & 6 & 43 & 8 & 46 & 6 & 47 & 9 & 35 & 10 \\
\hline COD & 97 & 33 & 97 & 19 & 56 & 19 & 59 & 17 & 63 & 21 & 66 & 18 & 125 & 100 \\
\hline \multicolumn{15}{|l|}{$(\mathrm{mg} / \mathrm{L})$} \\
\hline $\begin{array}{l}\mathrm{NH}_{4}-\mathrm{N} \\
(\mathrm{mg} / \mathrm{L})\end{array}$ & 24 & 5 & 24 & 3 & 12 & 3 & 13 & 3 & 14 & 4 & 15 & 3 & - & 2 \\
\hline $\begin{array}{l}\mathrm{TN} \\
(\mathrm{mg} / \mathrm{L})\end{array}$ & 30 & 11 & 30 & 7 & 28 & 7 & 29 & 6 & 29 & 7 & 29 & 6 & 15 & 35 \\
\hline $\begin{array}{l}\mathrm{PO}_{4}-\mathrm{P} \\
(\mathrm{mg} / \mathrm{L})\end{array}$ & 4.4 & 3.5 & 4.4 & 2.6 & 3.3 & 2.7 & 3.1 & 1.3 & 3.6 & 2.8 & 3.3 & 1.5 & - & - \\
\hline $\begin{array}{l}\text { E.coli } \\
\text { (Ulog/100 mL) }\end{array}$ & - & - & - & - & 5.4 & 2.4 & 5.4 & 1.9 & 5.4 & 2.4 & 5.4 & 1.9 & 3.7 & $1.7^{*}$ \\
\hline
\end{tabular}

\footnotetext{
*Maximum value to be detected in $80 \%$ samples for natural treatment systems.
} 
with, respectively, $50 \%$ and $100 \%$ restitution of ETc. While in A. donax plots the irrigation water applied, during spring/summer 2011 and 2012 , were $300 \mathrm{~mm}(50 \% \mathrm{ETc})$ and $600 \mathrm{~mm}(100 \% \mathrm{ETc})$ and $480 \mathrm{~mm}$ (50\% ETc) and $960 \mathrm{~mm}(50 \% \mathrm{ETc})$, respectively.

\section{Crop growth and biomass yield}

The increase of ETc restitution, from $0 \%$ to $100 \%$, positively influenced the plant higher and, consequently, the aboveground biomass production for all tested species (Table 2) while no significant difference were highlighted for different irrigation thesis. Biomass water content at harvest was lowest in M.giganteus, varying from 33 to $38 \%$, compared to A.donax (50-56\%) and V.zizanoides (62-65\%). This could be explained with the life cycle of plants: V.zizanoides and A.donax are active during most of the wintertime in the Mediterranean environment whereas the M.giganteus stems dry up completely during winter.

A.donax showed the highest values of dry biomass, with a mean value of about $50 \mathrm{t} \mathrm{ha}^{-1}$, followed by $M$. giganteus (-42\%) and V.zizanoides (-85\%). From first to the second year Arundo donax biomass dry yield decreased about $39 \%$ due to the reduction (about $-50 \%$ ) of the stalks density. The biomass yield of these species in the tested environment, has been higher (on average $+20-30 \%$ ) than recorded by other authors in two long-term experimental field carried out in Central (Angelini et al., 2009) and Southern Italy (Mantineo et al., 2009). These differences in yield performance can be linked to density planting (twice more than the other investigations).

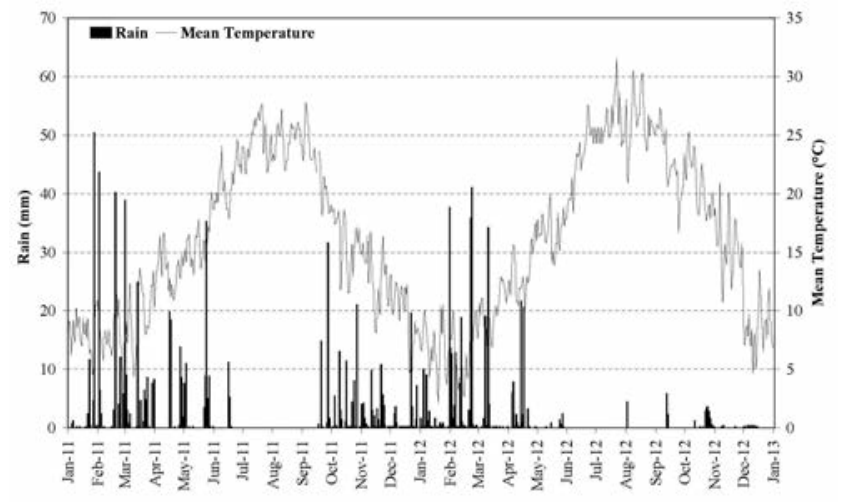

Figure 3. Precipitation and average air temperature series from January 2011 to December 2012.
The yield of V.zizanoides determined in this experiment showed values ranging between 2.6 to $16.6 \mathrm{t} \mathrm{ha}^{-1}$, that were comparable to those obtained in other similar field experiments carried out in North Italy ranging between 10 to $12 \mathrm{t} \mathrm{ha}^{-1}$ (Monti et al., 2005).

With regard to the 2012 yield of M.giganteus, it was observed that the high summer temperatures associated with an extended period without significant rainfall events, induced an early senescence state in M.giganteus plants without irrigation supply with subsequent dry biomass production failures. These environmental conditions have also influenced the yields of irrigated thesis decreased by $33 \%$ (50\% ETc) and 31\% (10\% ETc) than 2011 season. However, the average total biomass produced in the different irrigation treatments was comparable than recorded by other authors in experimental sites with similar climatic and crop management characteristics (Angelini et al., 2009; Mantineo et al., 2009; Zub and Brancourt-Hulmel, 2010).

\section{Ethanol yield}

The preliminary study on the chemical composition of biomasses investigated highlighted higher cellulose and hemicellulose concentrations in A.donax and M.giganteus while the V.zizanoides showed lower lignin content (Table 3). These fiber compositions of dry biomass samples were according with the data reported in the Phyllis database (http://www.ecn.nl/phyllis/single.html) and the BioBIB database (http//www.vt.tuwien.ac.at/biobib/). We can suppose that the A.donax and M.giganteus are the most suitable candidates for the production of fermentable sugars and ethanol by means of the appropriate pretreatment, hydrolysis and fermentation. Infact, the cellulosic and hemicellulosic fractions, are the most important biomass components that hydrolysates produce glucose subsequently fermented into ethanol (Currelli et al., 2002).

Despite the lower concentrations of cellulose and hemicellulose V.zizanoides showed higher fermentation yield (glucose percentage fer-

Table 3. Chemical composition of the herbaceous crops.

\begin{tabular}{lccccc} 
Species & $\begin{array}{c}\text { Extractives } \\
(\%)\end{array}$ & $\begin{array}{c}\text { Hemicellulose } \\
(\%)\end{array}$ & $\begin{array}{c}\text { Cellulose } \\
(\%)\end{array}$ & $\begin{array}{c}\text { Lignin } \\
(\%)\end{array}$ & $\begin{array}{c}\text { Ashes } \\
(\%)\end{array}$ \\
$\begin{array}{l}\text { Arundo } \\
\begin{array}{l}\text { Donax } \\
\text { Miscanthus } \\
\text { x giganteus }\end{array}\end{array}$ & $14,13 \pm 0,13$ & $33,57 \pm 0,57$ & $43,69 \pm 0,30$ & $8,68 \pm 0,25$ & $0,56 \pm 0,04$ \\
$\begin{array}{l}\text { Vetiveria } \\
\text { zizanoides }\end{array}$ & $18,98 \pm 0,33$ & $34,21 \pm 1,24$ & $46,14 \pm 0,58$ & $6,14 \pm 0,62$ & $1,15 \pm 0,02$ \\
\hline
\end{tabular}

Table 2. Mean values of density, height, moisture content and dry biomass evaluated of the herbaceous crops in December 2011 and 2012.

\begin{tabular}{|c|c|c|c|c|c|c|c|c|c|}
\hline \multirow[t]{2}{*}{ Species } & \multirow[t]{2}{*}{$\begin{array}{l}\text { Irrigation } \\
\text { thesis }\end{array}$} & \multicolumn{2}{|c|}{$\begin{array}{l}\text { Plant density } \\
\text { (n. plant/m²) }\end{array}$} & \multicolumn{2}{|c|}{$\begin{array}{l}\text { Height } \\
(\mathrm{cm})\end{array}$} & \multicolumn{2}{|c|}{$\begin{array}{c}\text { Moisture content } \\
(\%)\end{array}$} & \multicolumn{2}{|c|}{$\begin{array}{c}\text { Dry biomass } \\
\text { (t/ha) }\end{array}$} \\
\hline & & Dec - 11 & Dec-12 & Dec -11 & Dec-12 & Dec -11 & Dec-12 & Dec -11 & Dec-12 \\
\hline \multirow[t]{3}{*}{ Arundo donax } & 0\% ETc & 22 & 12 & 419 & 392 & 56 & 51 & 48.3 & 25.6 \\
\hline & $50 \%$ ETc & 22 & 14 & 475 & 437 & 56 & 50 & 59.5 & 40.9 \\
\hline & $100 \%$ ETc & 24 & 15 & 498 & 453 & 50 & 49 & 78.5 & 48.5 \\
\hline \multirow[t]{3}{*}{ Mischantus giganteus } & 0\% ETc & 83 & - & 119 & - & 38 & - & 19.6 & - \\
\hline & $50 \% \mathrm{ETc}$ & 85 & 73 & 179 & 168 & 37 & 51 & 30.6 & 20.6 \\
\hline & $100 \%$ ETc & 91 & 80 & 276 & 229 & 33 & 52 & 44.6 & 30.6 \\
\hline \multirow[t]{3}{*}{ Vetiveria zizanoides } & 0\% ETc & 4 & 4 & 96 & 91 & 65 & 69 & 2.6 & 3.7 \\
\hline & $50 \%$ ETc & 4 & 4 & 128 & 136 & 62 & 66 & 3.9 & 10.8 \\
\hline & $100 \%$ ETc & 4 & 4 & 169 & 168 & 63 & 66 & 7.0 & 16.6 \\
\hline
\end{tabular}


mented into ethanol) and ethanol production than those obtained for A.donax and M.giganteus (Table 4). These results could be mainly ascribes to the higher lignin content in A.donax and M.giganteus biomasses that has reduced the accessibility of cellulose to enzymes decreasing the hydrolysis rate (Currelli et al., 1997).

However, since the aboveground biomass yield per hectare is much higher for A.donax, the average ethanol yield per unit of cultivated area $\left(2,400 \mathrm{Kg} \mathrm{ha}^{-1}\right)$ was about 1.1 times the mean ethanol yield calculated for M.giganteus $\left(2,190 \mathrm{Kg} \mathrm{ha}^{-1}\right)$ and 3.4 times the average values of V.zizanoides $\left(710 \mathrm{Kg} \mathrm{ha}^{-1}\right)$.

\section{Conclusions}

The results of the experimental activities show that constructed wetlands are able in removing the main chemical and physical pollutants from the secondary effluent of urban wastewaters treatment plant. However, Escherichia coli (mean removal efficiency of about $3.3 \mathrm{log}$ unit) in CWs effluents didn't respect the Italian standard for wastewater reuse but complied with the WHO guidelines. In this case stabilisation reservoirs would be used coupling the CWs and would therefore be a reliable and economic solution to further reduce the microbiological load in treated wastewater (Barbagallo et al., 2003b).

The results highlight attractive biomass yield and an interesting crop energy capability by using treated wastewater for irrigation. The aboveground dry matter production, as expected, was positively affected by the full ET replenishment. The higher performance observed under $100 \%$ ETc restitution regime indicates that any effort to maximize and stabilize herbaceous biomass production might be subordinated to an adequate water supply. However, the A.donax showed significant biomass production even in the absence of irrigation with an average value of about $37 \mathrm{tha}^{-1}$.

The biomass and ethanol yield analysis showed highest values for A.donax and M.giganteus. This suggest the technical feasibility of extensive cultivation of these species on marginal land in the semiarid regions such as the Mediterranean area in order to maximise agricultural profits.

\section{References}

Angelini L.G., Ceccarini L., Nassi o Di Nasso N., Bonari E. 2009. Comparison of Arundo donax L. and Miscanthus x giganteus in a long-term field experiment in Central Italy: analysis of productive characteristics and energy balance. Biomass Bioenerg. 33:635-643.

APHA. Standard methods for the examination of water \& wastewater, 21st edn. Baltimore: American Public Health Association (APHA), AmericanWaterWorks Association (AWWA), and American Environment Federation (AEF); 2005.

ASCE-EWRI. The ASCE Standardized Reference Evapotranspiration Equation. Technical Committee report to the Environmental and Water Resources Institute of the American Society of Civil Engineers from the Task Committee on Standardization of Referente Evapotranspiration; 2004.

Barbagallo S., Cirelli G.L., Consoli S. and Somma F. (2003b). Wastewater quality improvement through storage: a case study in Sicily. Water Sci. Technol. 47:169-176.

Barbagallo S., Cirelli G.L., Marzo A., Milani M., Toscano A. 2011. Hydraulics behaviour and removal efficiencies in two H-SSF constructed wetlands for wastewater reuse with different operational life. Water Sci. Technol. 64:1032-1039.
Table 4. Glucose and ethanol concentration obtained, respectively, by the hydrolysis and fermentation processes and fermentation and ethanol yields.

$\begin{array}{lcccc}\text { Species } & \begin{array}{c}\text { Glucose } \\ (\mathrm{g} / \mathrm{L})\end{array} & \begin{array}{r}\text { EtOH } \\ \text { yield } \\ (\mathrm{g} / \mathrm{L})\end{array} & \begin{array}{c}\text { Fermentation } \\ \text { production } \\ (\%)\end{array} & \begin{array}{r}\text { Ethanol } \\ \mathbf{g}(\mathrm{EtOH})\end{array} \\ \mathbf{1 1 0 0 \mathrm { g } ( \mathrm { S } . S . )}\end{array}$

Barbagallo, S., Cirelli, G. L., Consoli, S., Toscano, A., Zimbone, S. M.. Performances and Hydraulics of a H-SSF constructed wetland for municipal wastewater reuse. In: Proceedings of 4th IWA International Symposium on Wastewater Reclamation and Reuse, 2003 November12-14, Mexico City, Mexico.

Barbera, A.C., Milani, M., Bellomia, L., Castiglione, V., Toscano, A., Cavallaro, V.. Effects of wastewater and different fertilization on Sorghum (Sorghum bicolor (L.) Moench) biomass production in mediterranean environment. In: Proceedings of 17th European Biomass Conference \& Exhibition from Research to Industry and Markets, 2009 June 28 - July 3, CCH-Congress Center, Hamburg, Germany.

Bedbabis S., Ferrara G., Ben Rouina B., Boukhris M. 2010. Effects of irrigation with treated wastewater on olive tree growth, yield and leaf mineral elements at short term. Sci. Hortic-Amsterdam, 126: $345-350$.

Borin M., Florio G., Barbera A.C., Cirelli G.L., Albergo R., Palazzo S.. Preliminary evaluation of macrophyte wetland biomasses to obtain second generation ethanol. In: Proceedings of 19th European Biomass Conference and Exhibition, 2011 June 6-10 2011. Berlin, Germany.

Cirelli G.L., Consoli S., Di Grande V., Milani M., Toscano A. 2007. Subsurface constructed wetlands for wastewater treatment and reuse in agriculture: five years of experiences in Sicily, Italy. Water Sci. Technol. 56:183-191.

Curreli N., Agelli M., Rescigno A., Sanjust E., Rinaldi A. 2002. Complete and efficient enzymic hydrolysis of pretreated wheat straw. Process Biochem. 37:937-941.

Curreli N., Fadda M.B., Rescigno A., Rinaldi A.C., Soddu G., Sollai F., Vaccargiu S., Sanjust E., Rinaldi A. 1997. Mild alkaline/oxidative pretreatment of wheat straw. Process Biochem. 32:665-670.

Ge X., Burner D.M., Xu J., Phillips G.C., Sivakumar G. 2011. Bioethanol production from dedicated energy crops and residues in Arkansas, USA. Biotechnol. J. 6: 6-73.

Gnansounou E. 2010. Production and use of lignocellulosic bioethanol in Europe: Current situation and perspectives. Bioresource Technol. 101:4842-485.

Italian regulation, 2003. Italian Technical Guidelines for Wastewater Reuse. D.M. 185/2003. In: Official Journal No. 169, 23/07/2003.

Italian regulation, 2006.

Mantineo M., D’Agosta G.M., Copani V., Patanè C., Cosentino S.L. 2009. Biomass yield and energy balance of three perennial crops for energy use in the semi-arid Mediterranean environment. Field Crop. Res. 114:204-213.

Monti A., Venturi G., Amaducci M.T.. Biomass potential and ash content of switchgrass, giant reed and cardoon in North Italy. In: Proceedings of 14th European Biomass Conference, 2005 october 17-21, Paris, France.

Paranychianakis N.V., Nikolantonakis M., Spanakis Y., Angelakis A.N. 
2006. The effect of recycled water on the nutrient status of Soultanina grapevines grafted on different rootstocks. Agr. Water Man. 81: 185-198.

Sivakumar G., Vail D.R., Xu J.F., Burner D.M., Lay J.O., Ge X., Weathers P.J. 2010. Bioethanol and biodiesel: Alternative liquid fuels for future generations. Eng. Life Sci., 10:8-18.
World Health Organization 2006. Guidelines for the safe use of wastewater, excreta and greywater, Volume 2: Wastewater Use in Agriculture. Geneva, Sweezerland.

Zub H.W., Brancourt-Hulmel M. 2010. Agronomic and physiological performances of different species of Miscanthus, a major energy crop. A review. Agron. Sustain. Dev. 30:201-214. 